\title{
Operations Partially Subject to the APA: Public Welfare Administration ${ }^{\dagger}$
}

\section{Jacobus tenBroek*}

In its administration of appeals in the public assistance programs-Old Age Security, Aid to the Needy Blind, Aid to Needy Children-the State Department of Social Welfare is not covered by the California Administrative Procedure Act. The California Supreme Court only recently so held, ${ }^{1}$ although this has always been the understanding on which the department has acted. This does not mean, however, that the department is free to set up or not, as it pleases, an appeal process for those who feel themselves aggrieved in welfare matters or to determine all of the features of that process if it is established. Both the Federal Social Security Act and the State Welfare and Institutions Code are explicit on this point. State public assistance plans, says the federal act, in order to receive federal participation, must provide for granting to any individual whose claim for aid is denied or not acted upon with reasonable promptness "an opportunity for a fair hearing" before the state agency responsible for the administration or the supervision of the administration of the state plan. ${ }^{2}$ Pursuant to this federal requirement, the State Welfare and Institutions Code provides for a right of appeal to the State Social Welfare Board. ${ }^{3}$ The appeal may be heard by the board or by a referee designated by the board. ${ }^{4}$ If heard by a referee designated by the board, he is required to present to the board "a report of the proceedings, ... together with any data the party appealing may desire ...." Only the board may make the final decision. ${ }^{6}$

To these statutory provisions has been added a body of administrative interpretation and supplementation, federal and state, further marking out the character of fair hearings and the role of the hearing officer. A hearing, says the Federal Handbook of Public Assistance Administration, "is an

i For assistance in collecting data used in this article the author is indebted to Ruth Brandit, Public Assistance Specialist II, Central Office, Appeals Section who prepared the charts used in this article; Allen Cooper, Administrative Advisor, State Department of Social Welfare; and Elizabeh MacLatchie, Chief, Division of Social Security, State Department of Social Welfare.

* Mr. tenBroek, Chairman Department of Speech, University of California, Berkeley, bas recently been re-appointed to the California Social Welfare Board. He is chairman of the Policy Committee. His numerous articles in the field of social welfare include Californio's Adoptiont Law and Programs, 6 HAST. L.J. 261 (1955); The Impact of Welfare Law Upon Family Law, 42 CALIF. L. REv. 458 (1954).

1 Bertch v. Social Welfare Dept., 45 Cal.2d 524, 289 P.2d 485 (1955).

234 STAT. 785 (1940), 42 U.S.C. $\$ \$ 302,503,602$ (1952).

3 CAI. Welf. \& INST. Code $\$ 104.1$.

4 Id. \$ 104.5(a).

5 Id. $\$ 104.5$ (c).

6 Ibid. 
orderly, readily available proceeding before an impartial official or panel of the state agency, in which a dissatisfied claimant of assistance or his representative may present his case with the help of witnesses to show why action or inaction in his case should be corrected by the state agency." 7 Included "in the consideration of the hearing process" is everything in the whole gamut of public assistance administration "from the initial notification to the individual regarding his right to a hearing, to the execution of the hearing decision ...."

The fair hearing process established by the state must incorporate the following procedural features: (1) written notice by the agency to all claimants of their right to a fair hearing when they feel themselves aggrieved by any agency action or inaction in colmection with their claim; (2) free choice on the part of every aggrieved claimant as to whether his grievance shall be handled through an informal complaint procedure or through a hearing before the state agency; (3) procedures assuring "prompt, definitive and final administrative action on every request for a hearing"; (4) hearings held "at a time, date and place convenient to the claimant" by qualified, impartial state agency officials, specifically assigned responsibility within the agency for conducting hearings, and according the claimant an opportunity to present evidence, witnesses and arguments, to examine all documents and records used at the hearing and to refute adverse testimony and evidence; (5) a hearing record or an official report of what transpired at the hearing which constitutes "the exclusive record for decision." 9 The hearing is not based upon the previous record made by the county at the time it took the action conplained of. It provides a new determination of the propriety of the claim at the time of the county action and may be based upon evidence since produced. ${ }^{10}$ The hearing officer is directed "to consult legal and policy authorities as necessary" but he is made solely responsible for the content of his report to the Social Welfare Board. ${ }^{11}$ The report contains the hearing officer's statement of: the essential facts; the pertinent statutory or policy provisions; the reasoning leading to the decision; and the recommended order. ${ }^{12}$

A state staff representative is available to both claimant and county to

7 Federat Handboor of PUbutc Asststance Admintstration $\$ 6210$.

8 Id. $\$ 6200$.

0 Id. $\$ 6310$.

10 Ord Age Security, Manual of Poltcees and Procedures (Cal. Dept. of Soc. Welf.) \$ 1500 "Forward"; Am to Needy Cimdoren, Manual of Polictes and Procedures \$ 600; Am to Needy Brind, Manual of Poticies and Procedures (Cal. Dept. of Soc. Welf.) \$ 710.

11 Old Age Security, Manual of Policies and Procedures (Cal. Dept. of Soc. Welf.) \$1544; Amd to Needy Chimbren, Manual of Policdes and Procedures (Cal. Dept. of Soc. Welf.) $\$ 644$; Am to Needy Blind, Manual of Policies and Procedures (Cal. Dept. of Soc. Welf.) $\$ 725$.

12 Ibid. 
explore the possibility of an adjustment before and during the appeal. She also aids the claimant by answering his questions and by helping him to secure records and other information needed in his appeal. Because the fee would necessarily be small and the work great in this intricate and unfamiliar field, claimants are not ordinarily represented by counsel and when they are counsel seldom makes a significant contribution. The state staff representative may attend the hearing to assist the claimant, the county or the referee, ${ }^{13}$ but seldom does so as a matter of practice since the department has been using its own hearing officers.

The seven members of the State Social Welfare Board all review all hearing officer reports. In addition the reports are divided up among the board members so that each case is closely scrutinized by a board member made particularly responsible for it. Bureau chiefs and other principal officials of the state staff are present at board meetings and are asked for policy information and other comment, especially in difficult cases. If there are questions of fact relating to any particular case, the board secures and distributes to all members a verbatim transcript of the entire hearing record. Changes in the hearing officer's findings of fact, whether the recommended order of the hearing officer is adopted, modified or reversed, are never made without such a transcript. Changes in the hearmg officer's statement of policy, reasoning, or in the recommended order dependent on these, often are made, regardless of whether the hearing officer's recommended order is adopted, modified or reversed. The board does not receive further testimony or argument from the county and claimant before modifying or reversing a hearing officer's recoinmended order whether the board takes a different view of the facts or of the law and policy. If the changes are minor and easily drafted, they may be made by the board itself at the meeting. Otherwise they are made by the staff at the board's direction, unless a rehearing or a further hearing is involved when the matter is remanded to the hearing officer. ${ }^{14}$ The board has learned from bitter experience that it is hazardous

13 Oid Age Security, Manual of Policies and Procedures (Cal. Dept. of Soc. Welf.) \$ 1548; Add to Needy Camdren, Manual of Policies and Procedures (Cal. Dept. of Soc. Welf.) \$648; Aid ro Needy Bitnd, Manual of Polictes and Procedures (Cal. Dept. of Soc. Welf.) $\$ 726$.

14 A curiously technical view of the difference between "rehearing" and "further hearing" was applied to social welfare appeals by the Los Angeles Superior Court in the case of Gilmore v. The Social Welfare Board (No. GLC 1622, Mar. 1955). The board had granted a rehearing and assigned the case to a second hearing officer. The rehearing was for the purpose of securing additional evidence. The record of the first hearing was not introduced at the second hearing. The hearing officer based his recommended order which was adopted by the board on the record of both hearings. The court in its opinion said that the proceedings were unfair because the board considered the record of the first hearing without the knowledge or consent of the petitioner's (second) representative. This the board could do if it designated the proceedings a "further hearing." 
to make changes on the spot with all seven members of an inexpert lay group participating. ${ }^{15}$

Decision by the board on a basis of the hearing officer's report has recently been reaffirmed as proper by the state supreme court against a charge that it violates the maxim that he who decides must hear. "[W] here," said the court, "petitioners were given a full opportunity to be heard before the hearing officer whose report was then reviewed by the board, there was no denial of procedural due process of law."16

In the course of the past decade, the Social Welfare Board has followed three methods of handling hearings: (1) It has itself heard the cases de novo; (2) it has used the hearing officers of the Division of Admimistrative Procedure, Department of Vocational and Professional Standards, under contractual arrangements between the two agencies; (3) it has employed its own hearing officers. These methods have been used in the order listed but one succeeded the other on an experimental and trial basis and there was consequently a good deal of overlap at various times. ${ }^{17}$ At present, the third method is employed exclusively. The reasons for moving from one to the other and the strengths and weaknesses of each as experienced in practice may or may not be peculiarly related to the structure and work of this particular agency.

The board hearings de novo were singularly inept performances. After the appeal request was filed, the state staff conducted a pre-hearing investigation. They interviewed the claimant and collected other evidence, when it seemed appropriate, from neighbors, friends, relatives, bank, real estate records and the like. They discussed the case with the county and reviewed the county records and contentions. They then set forth the results of their (1946).

${ }^{15} \mathrm{Cf}$. Pacific Indemnity Co. v. Industrial Accident Comm., 28 Cal.2d 329, 170 P.2d 18

16 Bertch v. Social Welfare Dept., 45 Cal.2d 524, 529, 289 P.2d 485, 488 (1955). The court apparently proceeded on the assumption in this case that, for the purposes of this doctrine, instances of board approval and disapproval of the hearing officer's recommended order were on the same footing. It did not qualify the statement of the doctrine in this regard and it made no reference in the opinion to whether the board had upset or sustained the hearing officer. As a matter of fact, the hearing officer had recommended denial of the appeal and the board had adopted this recommendation. The board had, however, changed findings of fact, statements about policy and reasoning, after all members had had the transcript. In this case, the court overturned both the hearing officer and the board, on a basis of the administrative record. It did not indicate whether it had read the verhatim transcript of the hearing or had reached its decision on a basis of the board's report. It did receive written and oral argument from the parties.

17 Some direct board hearings continued until as late as 1951 when they were brouglit to an end. Meanwhile in 1947 some use of hearing officers from the Division of Administrative Procedure (DAP) was begun and this method of handling hearings continued until 1953 when it was terminated in favor of department referees. Some use of department referees occurred as early as 1950 and they have been used with increasing frequency down to the present. In 1951 all three methods were in use. 
investigation in a memorandum stating the facts, disputed and undisputed, the arguments and conclusions of the county and the claimant, and the pertinent statutory and manual provisions. The memorandum did not include proposed findings, reasoning and order. The memorandum was sent to the county, the claimant and the board in advance of the board hearing.

These memoranda, thus prepared by the staff after a pre-hearing investigation and distributed to the parties and the board, were the focal points of the board hearings. In each case, the hearing was opened with an oral review by a staff member of the contents of the memorandum. The claimant and county, if present, were then invited to comment on the correctness of the memorandum and to give any additional testimony or argument. The claimant and the county were not required to appear. Since board meetings were seldom held outside of San Francisco and Los Angeles, more often than not the claimant did not appear. The same was often true of the small and remote counties though the larger and more accessible ones almost always had representatives present.

For a period of several years, the board members, at the close of the taking of evidence and argument, proceeded publicly to discuss the case and their decision, often calling on the staff for help. Unless the claimant asked for a private hearing, which he sometimes did (in which instance his case was put over to the end of the docket), the parties, other claimants, county representatives, and casual visitors all remained in the room and saw the board in the process of making up its mind. Performing thus under the eye of an audience, many of the board members proved reticent or excessively guarded in their comment and discussion. Even then members pulled some prize boners of iguorance or incapacity. When, for a time, there were organized client demonstrations in the audience, these were used as a welcome occasion for bringing to an end public decisions publicly arrived at. The board then developed the practice of withdrawing to a huddle in a corner of the room, still within full view but no longer within earshot of the audience, to engage in a more intimate and private discussion and to reach a conclusion which, after the public session was reconvened, was moved by a member selected in the caucus. Two of the principal staff members always joined the caucus and other staff members were summoned as needed.

The motions were likely to be brief, simply indicating that the appeal was denied or granted and if granted for how much. The extent to which the basis of decision was stated depended on the skill and interests of the particular board members or the chairman. After the meeting, the order of the board was formulated, sometimes by the chairman of the board, usually by the staff, and sent to the county and the claimant. Later, it was ratified by the board as part of the minutes of the meeting. 
As thus conducted, the board hearings de novo merited much criticism. When they were all over, a decision was reached in each case, it is true, but the claimant, the county, the state staff and the board members themselves frequently did not know or could not state what facts had been treated as the essential ones or what statutes and policies had been regarded as controlling, construed, and applied. No findings were prepared and issued. No systematic statement of reasoning was produced. Not only were these normal impediments to arbitrary or whimsical action absent, but the precedent, policy, and administrative significance of the cases was correspondingly reduced.

The claimant was not afforded a reasonably good opportunity to make an appeal. The time and place of holding the hearing were not arranged with an eye to his convenience unless he lived in one of the two main cities of the state and could turn up at the single session of two or three days held in each of them every other inonth. ${ }^{18}$ If age, infirmity, handicap or destitution did not prevent his making the meeting, he was likely to find the circumstances, procedure, audience, and seven-nian board, and his own ignorance and marticulateness baffling hindrances to the best presentation of his case.

The state staff was engaged in making an investigation by individual interviews and personal contacts which could more easily and better have been made by bringing the claimant, the county and the witnesses together at one time and place. On the one hand, the pre-hearing investigation was in effect a partial substitute for the hearing itself, and, on the other hand, it did not at the same time adequately perform the spade and shovel work for the board.

The board was called upon to perforn functions necessarily beyond the training and competence of a lay body representative of the community, namely, to unravel often coniplicated fact situations through the interrogation of parties and witnesses, to apply often complex statutes and manual sections to the facts thus elicited, to formulate the results for the claimant and the analysis through which those results were derived, and to do all this quickly and clearly in the course of a public nieeting. The board was called upon to do this, moreover, without the aid of counsel to the parties to conduct the questioning, prepare briefs and analyses, and draft proposed findings and order. Caught up in the process of collecting, sifting, and organizing detail, the board was able to give precious little time and attention to the larger task of determining the policy and administrative bearings of

18 On this ground the federal officials held that California's plan did not conform to federal requirements for a fair hearing. Letter from W. L. Mitchell, Acting Commissioner of Social Security, to Charles M. Wollenberg, Director, State Department of Social Welfare, August 27, 1947. 
individual cases and guaranteeing uniformity of treatment to claimants and recipients.

Most of the defects and difficulties of the board hearings de novo are or may be mitigated, if not cured, by the hearing officer system. With the use of hearing officers, the time and place of the hearing can be arranged at the convenience of the claimant. The hearing can be brought to him if he cannot come to the hearing. The hearing can proceed in the atmosphere of an informal conference, with the claimant put relatively at his ease. A skilled person is or may be on hand-the hearing officer-to aid the claimant in presenting his evidence and testimony and in ferreting out and formulating the issues. Proposed findings, reasoning, and order are worked out and submitted to the Social Welfare Board. The regular staff is relieved of its unnecessary and onerous investigatory duties in connection with hearings. The board is better able to perform its overall hearing and other functions. Whether all these potentialities of the hearing officer system become realities depends, of course, on the skill, training, knowledge, aptitude, and attitude toward the program and the claimants of the hearing officers and the relationship in which they stand to the agency.

On the questions of the desirability of having hearing officers with legal training and experience or social work training and experience, and having them independent of the agency or integrated into it, the weight of the evidence arising out of the years of experience of California's welfare administration with both types is on the side of social workers and integration.

Some of that evidence may be seen in the comparative rate of reversal by the board of hearing officers of the Division of Administrative Procedure (i.e., lawyers employed by another agency), and of board hearing officers (i.e., social work trained persons who are employees of the Social Welfare Department). As shown by the chart on the following page, the board reversed the former at a much higher rate than the latter.

Outright reversals of the recommended order constitute only a small fraction of the corrections made by the Social Welfare Board of the work of hearing officers. In addition, there are remands for further hearings, modification of the recommended order short of reversal, alterations in the findings, changes in the reasoning, and inclusions and exclusions of statutory and manual references. In these other respects, too, a substantially greater percentage of DAP hearing officer opinions and orders have had to be corrected than of department hearing officers' opinions and orders. In the six months period from July to December 1952, DAP hearing officers submitted 106 decisions of which fifty-four, or more than fifty per cent, required some change before adoption by the board. Of these changes, twenty-two orders were reversed; nine were amended substantially; three were returned for further hearings; and twenty required minor revisions. 
Fiscal Year $7 / 1 / 51-6 / 30 / 52$

$\begin{array}{crcc} & \text { Total } & \begin{array}{c}\text { Referees Proposed } \\ \text { Decisions Reversed }\end{array} & \begin{array}{c}\text { Percent } \\ \text { Reversed }\end{array} \\ \text { Decisions by SSWB } & 327 & 11 & 3.4 \\ \text { Heard by SSWB Referees } & 91 & 1 & 1.1 \\ \text { Heard by DAP Referees } & 227 & 10 & 4.4 \\ \text { Heard by SSWB } & 9 & & \end{array}$

Fiscal Year $7 / 1 / 52-6 / 30 / 53$

$\begin{array}{ccrr}\text { Decisions by SSWB } & 439 & 45 & 10.2 \\ \text { Heard by SSWB Referees } & 164 & 3 & 1.8 \\ \text { Heard by DAP Referees } & 275 & 42 & 15.2\end{array}$

Fiscal Year $7 / 1 / 53-6 / 30 / 54$

$\begin{array}{crrr}\text { Decisions by SSWB } & 559 & 31 & 5.5 \\ \text { Heard by SSWB Referees } & 502 & 23 & 4.5 \\ \text { Heard by DAP Referees } & 57 & 8 & 14.0\end{array}$

Fiscal Year $7 / 1 / 54-6 / 30 / 55$

$\begin{array}{llll}\text { Decisions by SSWB } & 575 & 7 & 1.2 \\ \text { All heard by SSWB Referees } & & & \\ \text { State Department of Social Welfare } & & \end{array}$

On the other hand, the department referee submitted eighty-two decisions of which sixteen, or nineteen and one-half per cent, were changed in some way. Of these, two were reversed; three were amended substantially; one was remanded for further consideration; and ten had minor changes. Corrections of both sets of hearing officers were unusually high in the second half of 1952. But the overall statistics for a three-year period show a continuing disparity between the two groups of hearing officers and in favor of the department enployees.

\begin{tabular}{lccccccc} 
& Total & Total DAP Number & \multicolumn{5}{c}{ Total SSWB } \\
Fiscal Year & Cases & Cases & Changed & Percentage & Cases & Changed & Percentage \\
$1951-1952$ & 327 & 227 & 42 & 18.5 & 91 & 5 & 5.5 \\
$1952-1953$ & 439 & 275 & 77 & 27.9 & 164 & 13 & 8.7 \\
$1953-1954$ & 559 & 57 & 16 & 28.0 & 559 & 39 & 7.7
\end{tabular}

One must recognize that there is a good deal of fluctuation in the percentage of correction needed in the work of both sets of hearing officers; that the quality of work turned out by the various individuals in each group varies greatly; that given individuals vary in their production from tine to time and type of problem to type of problem; that not all corrections are attributable to the character of the work of the hearing officers; that some result from the institution of new policy by the board, from unclear policy statements by the board, from the nuaking of decisions by the board in areas not hitherto covered by board decisions. One must recognize all this and 
make allowances for it in the above data. But when that has been done, the data are still striking as to the differences in the performance of the two groups. A good DAP hearing officer is better than a poor department hearing officer and vice versa. But given persons of generally the same intellectual competence and length of experience, the department hearing officer does the more satisfactory work.

The reason for this is not far to seek. It hes in the difference in training and experience and the relation of these to the kinds of problems which have to be handled. The scope and variety of issues raised and settled in social welfare fields are shown by the following chart.

Principal Issue

Age

Application refused

APSB

Blindness, Degree

Citizenship

Cooperation with Law Officers

Delay

Deprivation

Absent Parent

Incapacity

Other

Employment of Parent

Income

Need

Requirements

Special

Offer of Home

Property

Excess Personal

Transfer

Utilization

Other

Repayment

Residence

Stepfather Policy

Statute of Limitations

Miscellaneous

Total

\begin{tabular}{cc} 
Fiscal & Year $7 / 1 / 54-6 / 30 / 55$ \\
Total & Percent of Total \\
6 & 1. \\
3 & .5 \\
1 & .2 \\
14 & 2.4 \\
5 & .9 \\
7 & 1.2 \\
15 & 2.6 \\
& \\
24 & 4.2 \\
47 & 8.2 \\
4 & .7 \\
11 & 1.9 \\
49 & 8.5 \\
& \\
62 & 10.8 \\
46 & 8. \\
9 & 1.5 \\
& \\
53 & 9.2 \\
34 & 5.9 \\
12 & 2.2 \\
9 & 1.6 \\
24 & 4.2 \\
33 & 5.7 \\
58 & 10.1 \\
24 & 4.2 \\
25 & 4.3 \\
\hline 575 & 100. \\
&
\end{tabular}

State Department of Social Welfare

Some of these issues are routine such as the application of the ninetyday statute of limitations. Others, while not quite so simple as this, are yet basically of the same character smce they are rigidly controlled by well established and readily ascertainable procedures. The degree of blindness 
cases fall into this category. The controlling data are supplied by ophthalmologists and optometrists, chosen from a departmental list, who have examined the claimant for visual field and acuity, these being the two factors involved in the established definition of blindness. This exclusively physical definition of what is in large measure a social and economic handicap might be regarded as ill-adapted to the purposes of public assistance. However, it presents little administrative difficulty, and no particular challenge to the capacity or training of the hearing officers. ${ }^{19}$

Some of the issues are of the traditional type handled by lawyers and for which their training particularly prepares them-evaluating the various evidences of the date of birth; the types of activity and documents upon which a showing of citizenship may rest; the data indicative of intent to live in a place which, combined with a prescribed length of physical presence, constitutes residence. This is also true of some phases of the question whether the claimant has real or personal property in excess of the statutory limit allowable, a question the answer to which may turn on the distinction between a contract of sale of real property and a deed of trust with a promissory note, or on the legal significance of various encumbrances and estates, or on the meaning and character of various sorts of trusts, and so on. The so-called common-law stepfather cases are also in this group. They depend upon the application of the statutory presumption of a marriage in instances in which a couple live together and hold themselves out as man and wife. ${ }^{20}$ Somehow, the conception of a legal presumption is one that long eludes persons who do not have legal training. When handling such problems as those listed above, the law-trained hearing officer shows up to distinct advantage. He writes and acts (even a brief acquaintance with the cases before the board reveals), with a degree of ease, assurance and knowledge not possessed by the departnent hearing officer.

Issues of this type, however, are the determinative ones in only perhaps twenty per cent of the cases. Issues of a different sort preponderate-the determination of the needs of the claimant as those needs, basic and special, affect eligibility or the amount of the grant; evaluation of available income and resources to meet those needs; deprivation of parental support and care by reason of the incapacity of the parent defined medically and socially; assessment of the family and maternal factors upon which the employability of the mother of needy children rests; adequacy in the particular circumstances of each family situation of a plan for self-support and of the family's cooperation with the county in establishing it; the possibility of

19 So much is this so that one hearing officer complained of a feeling of "frustration of actually having nothing to decide when the average appeal is presented." Letter from Coleman E. Stewart, DAP hearing officer, to Charles Schottland, Director, SDSW, May 22, 1951.

20 Cat, Code CTv. Proc. $\$ 1963$. 
rehabilitation and the degree of cooperation with the Bureau of Vocational Rehabilitation; the suitability of a home offered to a child by a relative. Merely to mention these captions conveys immediately the complex social character of the determinations which have to be made. These are the areas in which persons with social welfare training and experience show up to advantage; in which they write and act with ease, assurance, and knowledge to a degree not generally possessed by law-trained hearing officers. Because of the prominence of these issues and judgments in social welfare appeals, the Federal Handbook sets forth the following as proper qualifications for a hearing officer: ${ }^{21}$

(a) Skills in the process of interviewing and examining which will enable him to obtain all pertinent evidence and to bring out the facts necessary to a fair determination of the case;

(b) Social work background enabling him to recognize social implications of the facts presented and to evaluate social evidence in his recommendation;

(c) Administrative experience enabling him to evaluate the evidence in such a way that he may: (1) explain to the claimant the laws and regulations under which the agency operates; (2) interpret to the state agency the evidence which indicates that selective policies, regulations, or practices need to be considered, clarified, or revised.

In addition to the fact that the DAP hearing officers have legal rather than social welfare training and experience, another factor explaining their comparative disadvantage as against department hearing officers is the difference in the degree of specialization on the job. ${ }^{22}$ DAP hearing officers serve other agencies as well as the Welfare Department. Department hearing officers are confined to social welfare appeals. This exclusiveness and concentration enables the department hearing officer to gain a better mastery of the substantive and procedural field in which the hearings occur, to keep up with changes great and small in legislative and board policy, to take note of the shifts and trends in the monthly output of the board; in short, to acquire the expertise which is sometimes said to characterize the actions of administrative agencies. It enables him to become, if he is not so already by virtue of his past training and experience, such a technician that he can accurately compute an Aid to Needy Children budget, an accomplishment often not achieved by the DAP hearing officer. One of the DAP hearing officers formerly serving the Welfare Department always declined

21 Federat Handbook of Public Assistance Administration $\$ 6410$.

22 The difference in training and background also appears to have a bearing on the atmosphere of the hearing. The hearing officers with social work training and background often seem more tolerant towards the claimant's ignorance and ineptitudes. The State Social Welfare Board found it necessary on a number of occasions to admonish DAP hearing officers who were badgering witnesses and claimants and lecturing them because of their answers. 
to hear an Aid to Needy Children budget case unless a department representative was sent along to help him; and indeed he was known to postpone such hearings until the department representative was able to appear. ${ }^{23}$

The role of the hearing officer in California's welfare administration is determined by the rules, statutory and administrative, state and federal, which have been mentioned, by the issues to be resolved in appeals and by the intricate and specialized character of some of the work. In addition to these factors, the role of the hearing officer is in large measure conditioned by the place of the fair hearing appeal in the overall administration of the public welfare programs. The process of hearing appeals is part and parcel of the other functions assigned the State Department of Social Welfare. Hearings are an aspect of policy determination and interpretation. They are as well instruments of administration.

In the welfare organization, the State Social Welfare Board and the State Social Welfare Board alone is empowered to make the decision in appeals. This is explicitly provided in the statutes. ${ }^{24}$ Moreover, it is an operational fact; not merely a legal fiction. Unlike the situation existing in many other agencies where the size of the case load makes this impossible, it is within the physical competence of the board actually to exercise the power. The board handles only 600 to 700 cases a year, or an average of fifty to sixty a month. It is consequently possible for the board to examine each case in detail and actually to decide it, though the board is a lay board, non-salaried and hence necessarily part-time. ${ }^{25}$ In this setup the hearing officer cannot be more than the agent of the board appointed to gather facts and to place those facts tentatively in their statutory and policy setting, preparatory to final judgment by the board.

The State Social Welfare Board is at the same time the body empowered to make the rules and regulations which supplement and implement the statutes. ${ }^{26}$ This duty is primarily discharged through elaborate machin-

23 See letter from unnamed hearing officer dated November 26, 1952 now located in files of California Department of Social Welfare in Sacramento under file number LA 30812 CA. Illustration of some of the points just made may be seen in the types of errors committed by DPA hearing officers and corrected by the State Social Welfare Board in February 1953: (1) Failure to consider code provisions; (2) Inclusion of irrelevant and objectionable material; (3) Failure to observe board precedents; (4) Failure to consider evidence; (5) Failure to obtain sufficient evidence; (6) Erroneous application of a regulation, and rendering decision contrary to the evidence; (7) Refusal to follow Board policy, and refusal to hold an additional hearing requested by the Board.

24 CAL. WeLF. \& INST. CODE $\S 104.5(\mathrm{c})$.

25 Members of the board receive "actual and necessary traveling expenses" plus $\$ 502$ month designated as "compensation" by CAT. WELF. \& INST. CODE § 101-an amount which barely covers "actual" but by some standards unnecessary expenses incident to the position.

26 CAL. WELF. \& INST. CODE \$ 103: "The Social Welfare Board hereby established, shall advise the director in the performance of his duties and formulate general policies affecting the purposes, responsibilities and jurisdiction under this chapter. The board shall have the power and it shall be its duty to adopt, promulgate, repeal and amend rules and regulations consistent 
ery carefully designed to enable interested groups, particularly the counties which carry on the direct administration of the programs, to scrutinize and criticize regulations before their adoption. All proposed regulations, whether submitted by the board, the state staff, the counties, or other interested groups or individuals, are subjected to examination by the state staff, the policy committee of the board, a representative committee composed of county supervisors and county welfare directors, a gathering of the county welfare directors, and finally, a public meeting of the State Social Welfare Board-all prior to final board action. In the operation of this primary machinery and sometimes in addition to it, the interpretive and policy making functions of the board are carried out always in the light cast by the appeals and not infrequently through them as an instrumentality. The appeals serve the board as a continuous and active test of policy. They show policy in operation and in concrete instances. They indicate whether a given regulation is working well and as contemplated when adopted. They quickly bring to light the inequities of policies in operation, their harsh, undue, and unanticipated results. Hard cases, as Justice Holmes commented, doubtless make bad law. The contrary is no less true and even more pervasive: Bad law or policy makes a lot of hard cases. Once these begin to pile up on the board, the information and experience are at hand necessary for the correction of policy. In some important areas, notably the rules regarding residence and those regarding the social aspects of incapacity in the incapacitated father cases, board policy underwent a rather complete evolution through the decisions on appeal before reformulation in the regulations. In addition to their important use as a test of existing policy, the appeals tend to disclose the desirability or need for establishing policy in areas not hitherto covered either by regulation or leading case decision. Finally, through the appeals the board is able to resolve the inevitable ambiguities, to fill the gaps, to clarify the unclear and to mark the outer boundaries of formally promulgated regulations. The connections between the interpretive functions of the board and the liandling of appeals are thus numerous, intimate, and of reciprocal advantage.

The board is also an organ of a department responsible for supervising the administration of the public welfare programs. The board does not itself any longer possess many administrative powers. These belong to the executive side of the department. Over the years there has been a systematic effort to withdraw from the board such administrative powers as it once possessed under the statutes and to vest these in the staff of the department,

with law for the administration of welfare. Except as otherwise provided by law, the board shall establish minimum standards of public assistance, not in conflict with law, for all relief purposes for which State grants-in-aid are made to the counties. The board sball have no administrative or executive functions other than those set forth in this code." 
leaving in the hands of the board the policy and appeal functions. These functions, lowever, are as closely associated with administration as the staff is with the board. The board has the formal power of advising the director of the department on administrative matters, ${ }^{27}$ and policy determinations are never made by the board without an evaluation of administrative problems and consequences. These functions, therefore, blend into each other as the work of the staff does with the work of the board. The fair hearing appeals directly serve an important administrative function. In fact, they are a process whereby the agency can correct administrative errors in individual cases, errors resulting from inadequate investigation, from miscomputations, from failure to accept and process papers, from clerical remissness, from social worker hostility or favoritism toward particular clients, or from inadvertent policy misinterpretation. On a broader scale, the fair hearing appeals are instrumentalities for the discovery and disapproval of county practices and policies which contradict, modify or misinterpret board policies and procedures. A surprisingly large number of such county practices and policies are brought to the attention of the board in just this way. Some counties, as a matter of fact, display a good deal of ingenuity in inventing interpretations which test the outer limits of established policies. Sometimes these interpretations are embodied in formal county rulings. ${ }^{2 s}$ Sometimes they are hidden in commouly understood practice among the workers either proceeding from a central source in county administration or evolving in case by case applications. Sometimes they are innocently founded in ambiguities of state policy or in the shadows of the fringes. Sometimes they are the product of county disagreement with the pohicy or of county reluctance to accept it at face value. Whatever the justification or the motivation, such county practices and policies are often brought to light by the appeals. If the county practice or policy resulted from inadvertence or the county was simply testing the meaning of the state regulation, the county complies with the board order handed down in the appeal and the practice or policy disappears. Otherwise, the county may refuse to comply with the order. In that event the board cites the county to appear before it and show cause why state and federal funds for the entire program should not be withheld. Thereafter, if the board stands its ground, the director of the state department is "advised" to withhold the funds, an action which he is willing to take since he has participated in the whole process. If the county is so convinced that its departure is sanctioned by law that it is ready to pursue the matter fur-

37 Ibid.

${ }^{28}$ County of L.A. v. Department of Social Welfare, 41 Cal.2d 455, 260 P.2d 41 (1953); tenBroek \& Wilson, County of Los Angeles v. State Social Welfare Department-A Criticism, 41 CAIIF. L. REv. 499 (1953). 
ther, it sues out a writ to restrain the state department and from there on the lawyers and the judges take over.

Fair hearings as an administrative process, used to correct prior administrative error and as a tool of policy and execution, when unsupported by other administrative techniques and devices, suffer from a number of weaknesses and limitations. Doubtless many applicants or recipients who feel themselves aggrieved do not bother to appeal. Still others do not feel themselves aggrieved though their rights and interests have been infringed or denied. Errors in these cases cannot be corrected by the appeal process. Moreover, as a result of these factors, the board may receive an incorrect, lopsided or distorted picture of facts and problems as they actually exist, an inadequate basis from which to build or test policy and administration. Finally, many cases can only be settled on their own more or less unique sets of facts and consequently cannot be used to establish or maintain a general rule. This is often true, for example, of residence cases in which decision turns on a combination of particular circumstances bearing on intent; or proof-of-age cases involving the weight to be attributed to the testimony of brothers and sisters or of a given Bible entry; or employmentof-mothers cases in which the question may be whether a child care arrangement proposed by the county is adequate. Even in such cases, of course, though the appeal may not have any general administrative significance, mistakes which have crept into the treatment of the individual can be corrected. However, fair hearings do not stand alone, unsupported by other administrative techniques and devices. They are indeed but one tool, though a very important one, in a complex of tools which form an integrated system of state supervision of county administration. Other tools in the complex are: spot reviews by state staff of samples of county case loads; reviews by state staff of individual cases to determine whether state and federal reimbursement to the county is proper or the county's claim for such reimbursement should be cut; special state staff studies of given problem areas in all or selected counties; an overall review of welfare administration in any given county; a continuous stream of financial, administrative, and case reports submitted to the state by all counties on stateprescribed forms; and finally, the ultimate sanction of withholding state and federal funds from a county for any particular program or for all programs. The selective use of these other tools enables the state staff and the board together to correct the weaknesses inherent in the appeals process as an administrative and policy determining device.

So far in this article, fair hearings in California's welfare administration have been analyzed primarily in terms of their administrative functions and relationships. What about fair hearings seen from the point of view of the individual applicant for or recipient of welfare benefits? To 
what extent are they an efficient mode for the protection of his rights and interests? Presumably, the protection of these was one of the principal purposes behind the institution of fair hearings in welfare. This seems clear from the language employed in the Federal Social Security Act: The state plan must provide "any individual whose claim for aid is denied or not acted upon with reasonable promptness an opportunity for a fair hearing."20 "A fair hearing," said one lawyer opposed to the whole idea, "has all of the implications of the father who presents one of his children as 'my legitimate son." "However that may be, the use of the word "fair" in the expression-not necessarily a redundancy if hearings have administrative and policy making functions - can only indicate a special emphasis on the rights and interests of the individual.

Interestingly enough, one of the justifications for administrative action, namely, that it can be taken quickly, has not been true historically of the appeals process in California's welfare system. Until very recently, a fair hearing was not a prompt hearing. On July 1, 1953, for example, of the 279 appeals pending, ninety ( $32 \%$ ) had been pending four months or more; forty-one $(15 \%)$ had been pending six months or more. The median time from the date an appeal was filed to the date of hearing was ninety-two days. The median time from filing appeal to board action was 151 days. In addition, a full year was allowed after the action or order complained of within which to file the appeal. From the claimant's point of view, the time involved in securing a final decision constituted a serious limitation on the value of the right of appeal. From the board's point of view, it not only involved the handling of a lot of stale claims, but the large amount of accumulated retroactive payment which a granting of an appeal entailed in some of these cases constituted a psychological and public relations barrier to a meticulous safeguarding of the claimant's rights and interests under the statutes and established policies.

The fair hearing time table has now been greatly speeded up. By July 1954, for example, of the 214 appeals pending, only seven (3\%) had been pending four months or more and none had been pending as long as six months. The median time from filing to hearing had been reduced from ninety-two to forty days and the median time from date of filing to final board action had been reduced from 151 to ninety-two days. The time within which an appeal could be taken was shortened by the Legislature in 1953 from one year to ninety days. ${ }^{30}$ The principal factor in bringing about these changes was the activity of a legislative interim committee which stimulated administrative improvement and secured legislation fixing a time limit for various stages of the appeal process. ${ }^{31}$ Other contributing factors

2934 StaT. 785 (1940), 42 U.S.C. \$§ 2(a) (4), 402 (a) (4), 1002 (a) (4) (1952).

30 CAI. WELF. \& INST. CODE $\$ 104.5$.

31 Id. §§ 104.1, 104.5. 
were a legislative provision, recommended by the department, permitting decision to be made on the issues only, leaving to the counties the details of computing specific amounts of aid in cases in which the amount of aid was not the issue; procedural changes instituted by the department which simplified the preparation for the appeal hearing; and the employment of additional department hearing officers to conduct hearings theretofore handled by DAP hearing officers.

Notwithstanding the cumbersomeness and delays of the appeals system -defects which in any event are not necessarily inherent in the system but can be overcome with a reasonable amount of effort and attention-the hearing officer program as currently organized and administered in California's welfare setup does work in fundamental respects to protect the rights and interests of the individual. Fairness to the individual begins with the substance of the laws and regulations. The laws are, of course, the product and the business of the Legislature. The regulations and policies are the product and the business of the board. Policy determinations made in the light of individual problems presented on appeal, as moderated and given perspective by information secured through other sources, are likely to embody a substance favorable to the equitable treatment of the individual. Doubtless this is especially true when the policy determiners are lay members of the community without professional training in the subjectmatter field. Fairness to the individual next proceeds through the flexible interpretation and modification of policy, once established, to remove injustices demonstrated in individual cases and in concrete detail by those who suffer them. Fairness to the individual, in the third place, is a matter of the procedural rights legally guaranteed and actually available to the claimant in establishing his claim to benefits under the statutes and policies as they stand. Finally, fairness to the individual involves supplying him with an opportunity to have a separate or judicial determination of his contention that the statutes are not consistent with the broader framework of the Constitution or the policies are not consistent with the statutes.

The fair hearing procedures employed in California's welfare administration meet reasonable formal criteria. All apphicants and recipients are fully informed of their right to appeal if they are dissatisfied in any way. The appeal machinery is readily available to them and easily set in motion. The hearing, once called for, cannot proceed without them. They can tell their own story or have it told for them by others of their choice. They can introduce all pertinent facts and many that are not pertinent. They can produce documents and witnesses. They are acquainted with all documents, evidence and witnesses used against them and have ample opportunity for refutation of material used against them. The factual record thus prepared is the basis of decision. 
For the intelligent, the articulate and the informed, these procedural safeguards are not only adequate but of the utmost importance. As explained earlier, few claimants come with lawyers and few lawyers, so appearing, make much contribution. Most welfare applicants or recipients are simply not able to utilize this machinery without a great deal of help. It is the help they are supplied which, in the end, converts these procedural safeguards into a hearing process fair to them. In some cases the help is supplied by private organizations such as the California Institute for Social Welfare or the California Council for the Blind. More often, it is supplied by the staff of area offices of the State Department of Social Welfare. Most of all, it is supplied by the liearing officer. Indeed, this is one of his principal functions. Many of the claimants who appear before him or to whom he brings a learing know only that they are dissatisfied and feel abused and mistreated. They don't know enough welfare law or policy to know what the issue is or how to state it. They are without competence and without a basis for judging the relevance or irrelevance of facts or testimony. It is the job of the hearing officer with sucli patience, forebearance, and skill as lie can muster, to listen to the claimant's story, to find and formulate the issue, to aid him in sorting out the evidence he has, and to indicate to him the ways in which he can establish his case. The county representatives who appear in opposition to the claimant need no such assistance. Without sucli help to most claimants, fair hearings would be a sham and a farce in whicli the elaborate machinery and procedural rights -drawn from precedents which presupposed the customary use of lawyers as professional helpers-would stand as cynical mockery of claimants who assayed to employ them but whose inability foredoomed them to failure. That the appeals process does in fact operate to protect the interests of the individual applicant or recipient can be seen from the percentage of cases in which the county action denying the individual's claim is reversed by the hearing officers and the board. The data taken from the board's appeal docket in Noveniber and October 1955 and October 1954 may serve as illustrative. (The number of appeals granted indicates the number of instances in which the county action is reversed.)

$\begin{array}{lccc}\text { Social Welfare Board Actions } & \text { Nov.'55 } & \text { Oct.'55 } & \text { Nov.'54 } \\ \text { Considered } & 62 & 53 & 36 \\ \text { Granted } & 30 & 31 & 15 \\ \text { Denied } & 24 & 14 & 16 \\ \text { Remanded to Referee } & 0 & 0 & 0 \\ \text { Continued } & 3 & 4 & 1 \\ \text { Dismissed } & 5 & 4 & 4 \\ \text { (Proposed decisions reversed } & 2 & 2 & 0 \text { ) }\end{array}$


A determination of the validity of regulations and policies under the statutes is commonly made in the appeal process. The counties are the greatest source of opposition to board regulations and policies on the merits or on the legality. When the counties or any of them determine to challenge the legality of a regulation, once the regulation has been adopted, the normal mode is to resist enforcement of an order resulting from an individual appeal by petitioning a court to restrain the board from taking enforcement action. If the counties do not seek judicial sanction for their position on questions of legality, they often seek legislative support. In either event, since the county board of supervisors and their employees, the county welfare directors, generally reflect the conservative influences of the community, their interposition is more likely to be against than in line with the interests of welfare applicants or recipients. Applicants and recipients, however, also enter challenges to the validity of regulations in the course of fair hearings and on the denial of their claim by the board, sometimes go on to seek judicial reversal. Sometimes the claimants do this on their own though of course eventually they have to hire a lawyer. Occasionally, a private institution which receives income or contributions from welfare recipients undertakes the support of such a fair hearing appeal and subsequent lawsuit. More often, private organizations of the blind or the aged interest themselves in the case and conduct the challenge and the court action. Counties, organizations, and individuals, but especially counties, often present arguments about the validity of regulations and policies when the regulations and policies are being considered by the board for adoption or afterwards. In fact, the board reviews policies, including questions of validity, upon petition to the board by individuals or groups or counties who are not at the time making use of the appeal process. Questions of validity are always sooner or later referred by the board or the department to the Attorney General and the board almost never persists in a policy deemed by the Attorney General to be beyond the statutes.

Much of the impetus for the development of a fair hearing program in public welfare has emanated from Federal Social Security officials. The character of that program is therefore a remarkable fact, for while the lawyers among the federal officials were evolving it and insisting on its adoption by the states the remainder of the Social Security Administration, and particularly the Bureau of Public Assistance, was striving mightily to secure throughout the country public assistance programs based on exactly contradictory principles: individual need individually determined and a personal means test. The basic principles and purposes of the fair hearing program as enunciated by the lawyers in the Federal Handbook are these: (1) The state agency is accountable to the claimant for any action or lack of action in relation to his claim; (2) he "may demand a hearing from the 
agency" therefore; (3) "the claimant may question the agency's interpretation of the law, and the reasonableness and equitableness of the policies promulgated"; (4) "the hearing is subject to the requirements of due process but should be an informal administrative procedure in order to serve best the interest of the claimant"; (5) the claimant must be safeguarded from "mistaken, negligent, unreasonable or arbitrary action" by administrators and workers; (6) to this end, he must be assured "uniformity in the application of the assistance law and policy." 32

A procedure or program which in any substantial degree implements these principles and purposes sounds the death knell of discretionary welfare benefits. It is altogether incompatible with individual need individually determined and a personal means test. These inescapable implications of a program of fair hearing appeals were articulated and expressly avowed as objectives of the federal lawyers in a semi-official article published in the Social Security Bulletin. "Due process," it is there maintained, "makes it essential that the people affected by the program be guaranteed equal protection under the law." "The claimant who meets the requirements established in the state law has a right to benefits and has a right to a hearing when he is denied these benefits." "The agency must clarify in its own mind and set down on paper the 'rules of the game.'" "Public assistance administration without mandatory standards, objective procedures and clearly defined policies becomes of necessity subjective and therefore autocratic. In such a setting, hearings are superimposed on agency operations, with the result that two irreconcilable elements meet, with serious effect for the participants."

Whether fair hearings are viewed as administrative tools for the selfcorrection of administrative error, or as aids and instruments of policy determination, interpretation and implementation, or as oriented to the protection of the rights and interests of the individual, or as a complex in which all of these elements are inseparably integrated, what is needed in hearing officers is not more independence of the agency but greater skill and ability; not more knowledge of law in general but less ignorance of the increasingly specialized and intricate law and policy of the subject field.

\footnotetext{
32 Federal Handbook of Pubtic Assistance Adnmiristration $\$ 6220$ and 6230.

33 Bernard W. Scholz, Hearings in Public Assistance, Sociar, SEcuRITy Buzr. July 1948, p. 14.
} 